\title{
Predation upon postlarval lobsters Homarus americanus by cunners Tautogolabrus adspersus and mud crabs Neopanope sayi on three different substrates: eelgrass, mud and rocks
}

\author{
Diana E. Barshaw*, Kari L. Lavalli \\ Boston University Marine Program, Marine Biological Laboratory, Woods Hole, Massachusetts 02543, USA
}

\begin{abstract}
To assess the anti-predator function and efficiency of burrows formed in different substrates, late Stage IV or early Stage V lobsters were placed in seawater tables with mud, rocks (some with algae), or eelgrass. They were allowed $4 \mathrm{~d}$ in which to settle and build burrows, after which predators were placed into half of the seawater table sections. The remaining sections served as predator-free controls. Censuses were taken of the number of lobsters without burrows during the $4 \mathrm{~d}$ preceding predator introduction. Following predator introduction, behavior of both lobsters and predators was observed to note how predators located and captured lobsters and how, if at all, lobsters escaped.The census data showed that more lobsters had burrows in the rock substrates than in either the eelgrass or mud substrates. Fewer lobsters had burrows in mud substrates than in eelgrass substrates. When subject to predation by cunners Tautogolabrus adspersus, no predation occurred in the rock substrate. However, significant predation occurred in the mud and eelgrass substrates. When subject to predation by mud crabs Neopanope sayi, predation occurred in all 3 of the substrates.
\end{abstract}

\section{INTRODUCTION}

Numerous studies have suggested that postlarval and juvenile lobsters are subject to high predation pressure by fishes and crabs. Cunners have been found to have early juvenile lobsters in their guts (Bigelow \& Shroeder 1953). Roach (1983), in cage experiments in the field, found that crabs Cancer irroratus and fish Myoxocephalus spp. were able to capture lobsters in mud substrates, but these predators were not successful in rock substrates. Lavalli \& Barshaw (1986) found that, although burrows in rocks protected early juvenile lobsters from cunners Tautogolabrus adspersus, they did not protect the juveniles from mud crabs Neopanope sayi. Johns \& Mann (1987) found that bricks with vegetation reduced predation upon juvenile lobsters by cunners, but mortality was still high. Many investigators have assumed that if settling lobsters are able to build a burrow in an appropriate substrate they will be free from predation (Atema et al.

\footnotetext{
- Present address and address for correspondence: Marine Field Station, Rutgers University PO Box 278, Tuckerton, New Jersey 08087, USA
}

1982, Botero \& Atema 1982, Pottle \& Elner 1982, Aiken \& Waddy 1986). Clearly, the above-mentioned experiments do not support this assumption in the literature.

Barshaw \& Bryant-Rich (in press) found that lobsters started burrowing more quickly in eelgrass and rocks than in mud. Both Herrick (1895) and MacKay (1926) noted that juvenile lobsters were occasionally found in eelgrass. Thus, eelgrass, which had not been previously tested in conjunction with lobsters, might be an appropriate substrate for early juvenile lobsters and should be included in experiments comparing lobster behavior in different habitats. This experiment expands on the previous experiment of Lavalli \& Barshaw (1986), by comparing the protective qualities of 3 substrates in which postlarval lobsters can burrow: mud, eelgrass and rocks, against the same 2 predator species used previously, cunners and mud crabs.

\section{MATERIALS AND METHODS}

Large seawater tables were divided into thirds by plastic partitions with holes which allowed water to flow through the sections, but prevented movement of 
lobsters between sections (dimensions of each section: $76 \mathrm{~cm}$ long $\times 44 \mathrm{~cm}$ wide $\times 40 \mathrm{~cm}$ high). The sections contained either a cohesive mud substrate $(10 \mathrm{~cm}$ deep), an eelgrass substrate (10 to $15 \mathrm{~cm}$ deep) or a rocky substrate $(12 \mathrm{~cm}$ deep) composed of rocks of a natural size distribution $(0.1$ to $20 \mathrm{~cm}$ in diameter), some of which were covered with Fucus spp. The substrates were placed into the sections in a latin square to negate any possible effect of flow rate on the results. All of the substrates were obtained from subtidal areas in Woods Hole, Massachusetts, USA. Particular care was taken with the eelgrass substrate to keep it healthy. The eelgrass was allowed at least $3 \mathrm{wk}$ in large outdoor seawater raceways to recover from transplantation before being used in the experiment Fluorescent lights were placed above all sections and run on a $14: 10 \mathrm{~h}$ day: night schedule to keep the eelgrass alive throughout the runs.

After being placed into the sections, all substrates were allowed to acclimate for $1 \mathrm{wk}$ and were carefully checked for the presence of small fish and crabs, which were removed as found. During the final crab runs (September-October) we could not locate all of the naturally occurring mud crabs in the eelgrass substrate since mud crab recruitment had occurred prior to the collection of the substrate. Because of this problem the eelgrass controls contained predators, and thus could not be used in the analysis.

Cunners were held communally for not more than $5 \mathrm{~d}$ and were fed Stage IV lobsters $2 \mathrm{~d}$ prior to being used. Likewise, the crabs were held for no longer than $14 \mathrm{~d}$ prior to testing and were fed Stage IV lobsters $3 \mathrm{~d}$ prior to use.

Six treatments were used: 3 sections containing mud and predators, 3 sections containing eelgrass and predators, 3 sections containing rocks and predators, and an identical number of replicate sections for each substrate without predators. These latter replicate sections were the controls to determine mortality caused by factors other than predation. Two runs using cunners and 3 runs using mud crabs were conducted (the third crab run was conducted only on the rock substrate). After the $1 \mathrm{wk}$ substrate acclimation period, 10 late Stage IV or early Stage V lobsters were placed into each section. Upon release into each section, the lobsters were given $4 \mathrm{~d}$ in which to settle and build burrows. During this time, the lobsters were fed once daily with frozen brine shrimp. On the fourth day, we ceased feeding the lobsters and introduced the predators. For each run we introduced either 3 cunners or 8 mud crabs into each experimental section. The cunners ranged in size from 6 to $10 \mathrm{~cm}$ (total length) while the mud crabs ranged from 8 to $25 \mathrm{~mm}$ in carapace width. By using large, medium and small animals in each tank we made sure that the average predator size was similar for each tank.

Censuses were taken 4 times daily on the number of lobsters remaining without burrows. In the rock substrates lobsters were assumed to be burrowed if they could not be seen. Observations of $30 \mathrm{~min}$ were made on the behavior of the predators following their introduction to each section to note the methods by which the predators caught and consumed the lobsters, and the escape behavior of the lobsters. Four days after the introduction of the predators the substrates were sorted to determine the number of surviving lobsters.

The burrow data was analysed with a 3-way ANOVA for (1) differences between sections, (2) differences between concurrent runs and (3) differences between substrates. The survival data were analysed for differences between controls and experimentals and between substrate types using contingency tables analysed with Chi-Square tests. The 2 fish runs and the first 2 crab runs were pooled after it was determined that the $\chi^{2}$ values were homogeneous. (Chi-Square test, $p>0.1$.) However, the final crab run was significantly different from the previous 2 and is reported separately (Table 1).

Table 1. Homerus americanus. Percent of lobsters surviving at the end of the experiment, in treatments with cunners and mud crabs as predators. C: control; E: experimental; EG: eelgrass

\begin{tabular}{|c|c|c|c|c|}
\hline Predators & Mud $E / C$ & Rock $E / C$ & Eelgrass E/C & Chi-Square test \\
\hline $\begin{array}{l}\text { Cunners } \\
\text { ( } 2 \text { runs } \\
\text { combined) }\end{array}$ & $\begin{array}{c}\cdots \\
8.3 / 85.0\end{array}$ & $\begin{array}{c}\mathrm{NS} \\
71.7 / 80.0\end{array}$ & $\begin{array}{c}\cdots \\
14.4 / 75.5\end{array}$ & $\begin{array}{l}\text { Mud vs Rock: } p<0.001 \\
\text { Mud vs EG: NS } \\
\text { Rock vs EG: } p<0.001\end{array}$ \\
\hline $\begin{array}{l}\text { Mud crabs } \\
\text { ( } 2 \text { runs } \\
\text { combined) }\end{array}$ & $\begin{array}{c}\cdots \\
26.7 / 82.0\end{array}$ & $\begin{array}{c}\mathrm{NS} \\
83.2 / 91.7\end{array}$ & $6.7 / \cdots$ & $\begin{array}{l}\text { Mud vs Rock: } p<0.001 \\
\text { Mud vs EG: NS } \\
\text { Rock vs EG: } p<0.001\end{array}$ \\
\hline $\begin{array}{l}\text { Mud crabs } \\
\text { (3rd run) }\end{array}$ & & $\begin{array}{c}\ddot{1} \\
3.7 / 83.3\end{array}$ & & \\
\hline $\begin{array}{l}p<0.001 \\
\text { Control failed }\end{array}$ & & & & \\
\hline
\end{tabular}


These experiments were conducted from June through October 1986 at the Marine Biological Laboratory, Woods Hole, Massachusetts, USA. Water temperatures ranged from 18 to $23^{\circ} \mathrm{C}$.

\section{RESULTS}

\section{Burrow data}

No significant differences were found between the number of lobsters without burrows in the eelgrass and rock substrates over the 3 runs. However, the third mud run did show a significantly greater number of lobsters without burrows than either the first or second mud run (ANOVA, $p<0.001$; Newman-Keul's test, $p<0.05$ ). Because of this difference, data from the first and second run were combined whereas data from the third run were depicted separately (Fig. 1).
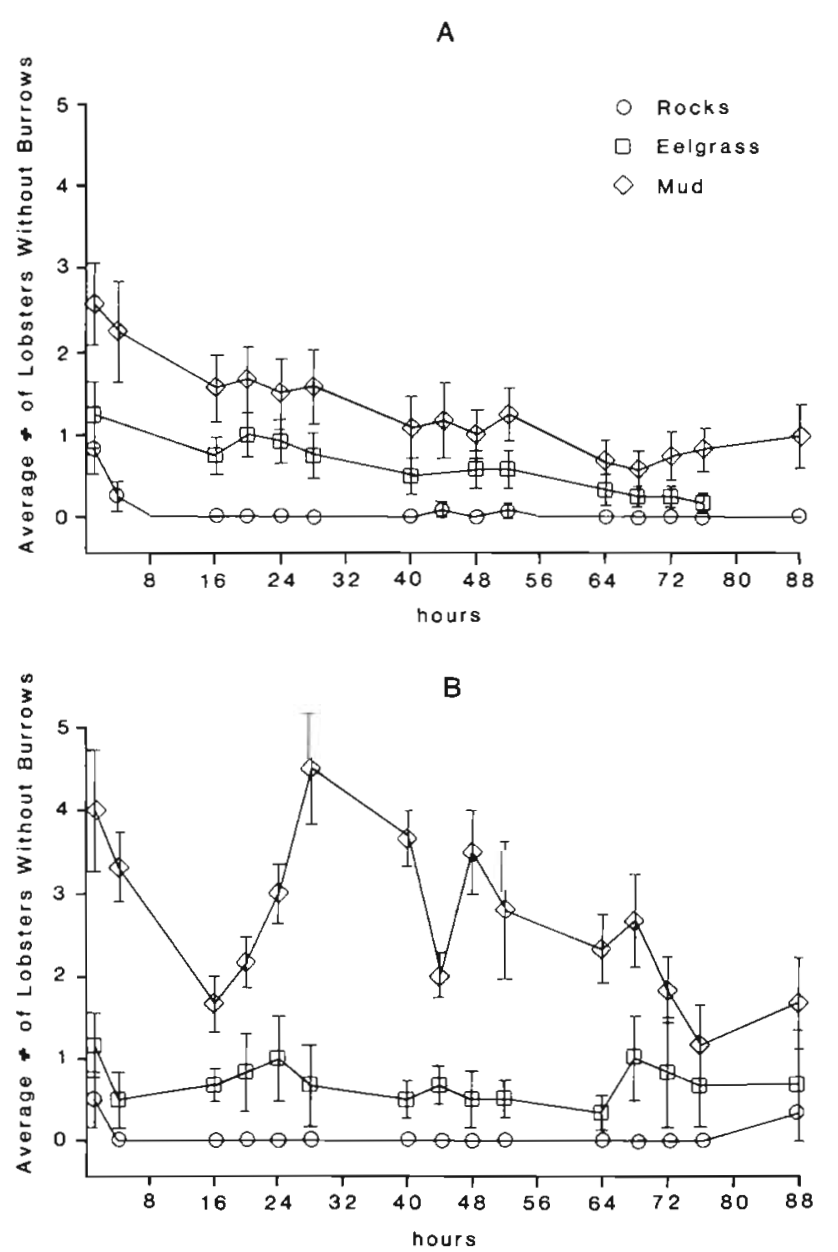

Fig. 1. Homarus americanus. Average number of lobsters out of 10 that did not have burrows in mud, eelgrass and rock substrates during the first $88 \mathrm{~h}$ of the experiment (before predators were introduced). (A) Runs 1 and 2 combined.

(B) Run 3
A significantly greater number of lobsters were without burrows in the mud substrates than in either the eelgrass or rock substrates, and there were a greater number of lobsters without burrows in the eelgrass substrate than in the rock substrate. This relationship was true for both Run 1 and 2 combined and for Run 3 (ANOVA, $p<0.001$; Newman-Keul's test, $p<0.05$; Fig. 1). We commonly saw the burrows in the mud substrate collapse, leaving only a depression, often causing that lobster to resume either walking or swimming before constructing a new burrow.

\section{Behavior}

On several occasions during the observation periods we saw cunners catch lobsters in both the mud and eelgrass substrates. Their methods of capture differed slightly depending on the substrate. In mud substrate the cunners would typically locate a burrow and wriggle above it until it collapsed forcing the lobster to flee. The lobster's tail-flip response was of little use in escaping the much faster fish. Actual consumption took place in a fraction of a second with the fish sucking the whole lobster into its mouth, usually tail first. Cunners used similar methods to catch the lobsters in eelgrass, however destroying the burrows seemed more difficult. On one occasion a cunner was seen putting its snout into the entrance of a burrow and twisting its body forward until the burrow collapsed. On another occasion a cunner actually seemed to suck the lobster out of an eelgrass burrow.

Mud crabs destroyed lobster burrows in mud by repeatedly walking over them. However, the lobster had a much better chance of escape from the crabs than from the cunners. The crabs could not capture the lobsters when they tail-flipped away; consequently, the crabs were only successful at capturing the lobsters by pouncing upon and grabbing them with both claws. It took the crabs more than $10 \mathrm{~min}$ to completely consume a lobster once captured. It is possible that the crabs caught the lobsters by actually going into their burrows, particularly in the eelgrass and rock substrates since we saw a crab chase a lobster out from under a rock.

\section{Survival}

Lobsters in the rock substrate were protected from cunners as there was no significant difference between the experimental and control treatments. However, cunners were able to prey upon the lobsters in both the mud and the eelgrass substrates, as survival was significantly less in the experimental than in the control 
treatment for both of those substrates. There was no significant difference in survival between the eelgrass and mud substrates (Table 1).

With mud crabs as the predator, survival in the mud experimental treatment was significantly less than in the control (Chi-Square test, $p<0.001$ ), indicating that mud crabs were able to consume lobsters in the mud substrates. Mud crabs were also able to prey upon the lobsters in the eelgrass substrate since only $6.7 \%$ of the lobsters survived in the experimental treatment. The mud crabs did not prey upon the lobsters in the rock substrates during the first 2 runs since there was no significant difference between the rock experimentals and controls. Because this result contradicted the results of Lavalli \& Barshaw (1986), a third rock run was conducted. In the third run the mud crabs did consume the lobsters in the rocks (Chi-Square test, $p<0.001$; Table 1).

\section{DISCUSSION}

Results on the average number of lobsters without burrows in each substrate agree with previous studies (Botero \& Atema 1982, Pottle \& Elner 1982, Barshaw \& Bryant-Rich in press). We found that the lobsters in mud were without burrows most frequently, followed by eelgrass, and then rocks (which had the lowest average number of lobsters without burrow). It is unclear what caused the lobsters of the third mud run to have fewer burrows than the lobsters of the first 2 mud runs. Perhaps the mud had become less cohesive with time. In any case the relationship between mud rocks and eelgrass versus the number of lobsters without burrows was the same for all 3 runs.

The survival data indicate that lobster burrows do not offer as much protection against predation as has often been assumed in the literature. Mud crabs were able to prey upon the lobsters in all of the substrates tested. Furthermore, only the rock substrates provided complete protection against cunners. Burrows in both mud and eelgrass provided more protection from the cunners than depressions in sand where no lobsters survived (Lavalli \& Barshaw 1986); however, significant predation did occur in these substrates.

An interesting discrepancy was seen in the behavior of the mud crabs. While in Lavalli \& Barshaw (1986) and in the third run of this experiment the mud crabs did prey upon the lobsters burrowed in the rocks, predation did not occur during the first and second crab runs of this experiment. If the difference were caused by a seasonal change in the behavior of the crabs (e.g. a mating period) we would expect it to have disrupted feeding equally in the other substrates; yet predation did occur in the eelgrass and mud runs which ran concurrently with these first 2 rock runs. However, even with this inconsistency, the results show that mud crabs can prey on early juvenile lobsters burrowed in rocks - why they do not always do so remains unanswered

Our results showing that burrows in eelgrass do not provide lobsters with more protection than mud substrates seems to conflict with the many studies which indicate that eelgrass provides more protection than a less complex substrate (Reise 1978, Nelson 1979, Coen et al. 1981, Heck \& Thoman 1981, Stoner 1982, Peterson 1982). However, cunners Tautogolabrus adspersus and mud crabs Neopanope sayi used as predators in this experiment were not used in any of the abovementioned studies. While we expected that a burrowing animal like the mud crab would be able to capture the lobsters in these environments, it was less evident that the cunners could do so. Experiments comparing predation strategies of cunners to other fish would be useful. Also in this experiment the predators were allowed $4 \mathrm{~d}$ in a restricted space to forage for the lobsters while most of the above-mentioned experiments on predation in eelgrass allowed only from 1 to $24 \mathrm{~h}$, with the longest period being $2 \mathrm{~d}$. The longer time scale could have made it more difficult to detect small differences between the rates of predation in the mud versus the eelgrass, although the lobsters were never completely consumed in either of these substrates.

This experiment was not designed to provide data on the absolute predation rate lobsters experience in the field. Laboratory experiments, which by necessity are conducted in tanks, restrict the movements of at least the predators and thus change the rate of predation. However, these data do allow one to compare habitats and the efficiency of the predators in each habitat.

Acknowledgements. We thank Donald R. Bryant-Rich for his help with experimental design and for his assistance collecting all of the substrates. We thank Ken Able of the Rutgers University Marine Field Station for his helpful review of the manuscript. We also thank Mike Syslo and Kevin Johnson of the Martha's Vineyard State Lobster Hatchery, and Jean Frazer and Barb Beltz from the New England Aquarium for supplying us with Stage IV lobsters. This research was supported in part by an Environmental Conservation Fellowship from the National Wildlife Federation to DEB.

\section{LITERATURE CITED}

Aiken, D. E., Waddy, S. L. (1986). Environmental influence on recruitment of the American lobster, Homarus americanus: a perspective. Can. J. Fish. Aquat. Sci. 43: 2258-2270

Atema, J., Leavitt, D. F., Barshaw, D. E., Cuomo, M. C. (1982). Effects of drilling muds on the behavior of the American lobster, Homarus americanus, in water column and substrate exposures. Can. J. Fish. Aquat. Sci. 39: 675-690

Barshaw, D. E. Bryant-Rich, D. R. (in press). A long-term study on the behavior and survival of early juvenile Ameri- 
can lobsters, Homarus americanus, in three naturalistic substrates: eelgrass, mud, and rocks. Fish. Bull. U. S.

Bigelow, H. B., Schroeder, W. C. (1953). Fishes of the Gulf of Maine. Fishery Bulletin 74, Vol. 53. Fishery Bulletin of the Fish and Wildlife Service, U.S. Government Printing Office, Washington, D. C., p. 473-478

Botero, L., Atema, J. (1982). Settlement and substrate selection during larval settling in the lobster, Homarus americanus. J. Crust. Biol. 2: 59-69

Coen, D. L., Heck, K. L., Abele, L. G. (1981). Experiments on competition and predation among shrimps of seagrass meadows. Ecology 62 (6): 1484-1493

Heck, L. H., Thoman, T. A. (1981). Experiments on predatorprey interactions in vegetated habitats. J. exp. mar. Biol. Ecol. 53: 188-189

Herrick, F. H. (1895). The American lobster; a study of its habits and development. Bull. U.S. Fish Comm. 15: 188-189

Johns, P. M., Mann, K. H. (1987). An experimental investigation of juvenile lobster habitat preference and mortality among habitats of varying structural complexity. J. exp. mar. Biol. Ecol. 109: 275--285

Lavalli, K. L., Barshaw, D. E. (1986). Burrows protect postlarval lobsters Homarus americanus from predation by the non- burrowing cunner Tautogolabrus adspersus, but not from the burrowing mud crab Neopanope texani. Mar Ecol. Prog. Ser. 32: 13-16

MacKay, D. A. (1926). Post-larval lobsters. Science 64: 530

Nelson, W. G. (1979). Experimental studies of selective predation on amphipods: consequences for amphipod distribution and abundance. J. exp. mar Biol. Ecol. 38: 225-245

Peterson, C. H. (1982). Clam predation by whelks Busycon spp: experimental tests of the importance of prey size prey density, and seagrass cover. Mar. Biol. 66: 159-170

Pottle, R. A., Elner, R. W. (1982). Substrate preference behavior on juvenile American lobsters, Homarus americanus, in gravel and silt-clay sediments. Can. J. Fish. Aquat. Sci. 39: 928-932

Reise, K. (1978). Experiments on epibenthic predation on the Wadden Sea. Helgoländer wiss. Meeresunters. 31 55-101

Roach, G. S. (1983). Survivorship, growth, and behavior of juvenile lobsters, Homarus americanus Milne-Edwards in controlled environments in nature. Manuscript and Technical Report Series, Nova Scotia, Department of Fisheries, Rept. \#83-02

Stoner, A. W. (1982). The influence of benthic macrophytes on the foraging behavior of pinfish, Lagodon rhomboides (Linnaeus). J. exp. mar. Biol. Ecol. 58: 271-284

This article was presented by Dr R. S. Scheltema, it was accepted for printing on June 29, 1988 